\title{
Chemical investigation of the spray of the Asian whipscorpion Typopeltis crucifer Pocock, 1894
}

\author{
Hideki Itokawa,* Rokuro Kano,* Shigeru Kaneko,** Terumi NakajImA**,1) \\ Tadashi YASUhara*** and Sonden YonabarU $* * * *$ \\ * Department of Medical Zoology, Faculty of Medicine, Tokyo Medical and \\ Dental University, Bunkyo-ku, Tokyo 113, Japan \\ ** Division of Molecular Biology, Institute for Medical and Dental Engineering, \\ Tokyo Medical and Dental University, Chiyoda-ku, Tokyo 101, Japan \\ *** Institute of Pharmaceutical Sciences, School of Medicine, \\ Hiroshima University, Hiroshima 734, Japan \\ **** Yaeyama Health Center, Ishigaki, Okinawa 907, Japan
}

(Received : November 17, 1980)

\begin{abstract}
The spray of the Asian whipscorpion, Typopeltis crucifer Pocock, 1894, was investigated chemically using a high performance liquid chromatograph and a gas chromatograph-mass spectrometer. The spray mainly consists of acetic acid, caprylic acid, and water. No other fatty acids, other volatile materials or active amines can be detected in the spray. The adult discharged ca. 5 to $15 \times 10^{-5} \mathrm{~mol}$ of the total acid in the 1st shot. Contents of the major components were determined by massfragmentography and the following results were obtained: acetic acid, $81.7 \%$ (v/v); caprylic acid, $5.4 \%$ (v/v); water, $12.9 \%(\mathrm{v} / \mathrm{v})$. These values are quite similar to those of the American species, Mastigoproctus giganteus (Lucas, 1835).
\end{abstract}

\section{INTRODUCTION}

The Asian whipscorpion (Typopeltis cruci$f e r)$ is distributed through southeast China to the southern part of Nansei Islands, Japan. It sprays the vinegary fluid from intraabdominal glands, which consist of a pair of voluminous sacs, as a defensive action against predators. The whipscorpions are thought to be Carboniferous animals with little morphological change since then. A similar species belonging to a

1) To whom correspondence should be addressed.

* 米川英樹, 加納六郎：東京医科菌科大学医学部医 動物学教室（干̄113 東京都文京区湯島 1-5-45）

** 金子 茂, 中嶋暉躬: 東京医科歯科大学医用器 材研究所生理活性部門（广101 東京都千代田区 神田駿河台 2-3-10)

***安原 義 : 広島大学医学部総合薬学科薬品化学 教室（干734 広島市霞 1-2-3）

**** 与那原孫伝: 八重山保健所 (下907 沖繩県石垣 市真栄里 436) different genus, Mastigoproctus giganteus, occurs in the Neotropical region including Central America and North America. The substance in the spray of this species was identified as a mixture of acetic acid and caprylic acid (Eisner et al., 1961). With a chemotaxonomical interest, we have examined the spray of the Asian whipscorpions collected on Ishigaki Island, Okinawa Prefecture. The present report deals with the chemical analysis of the spray of this species. Skin irritation and corneal opacity caused by the spray of the whipscorpion were observed.

\section{Materials AND Methods}

\section{Collection of the sample}

More than 20 whipscorpions were collected under stones at Mt. Omoto, Ishigaki Island on 29 May, 1980. Each of them was kept in a glass cage and fed cockroaches. The vinegary fluid discharged, when the body was seized, was collected individually into small glass tubes. 


\section{Instrumentation}

Liquid chromatography for the detection of active amines and amino acids was performed by the method described previously (Yoshida et al., 1978), using TSK Gel LS-210 (Toyo Soda Co.) and by a post-labelling method with o-phthalaldehyde (Benson and Hare, 1975). Mass spectra were obtained by a combined gas chromatograph-mass spectrometer (JEOL JMS D 300) on 2 kinds of glass columns: 1) $3 \mathrm{~mm}$ i.d. $\times 2 \mathrm{~m}$ length, packed with $3 \%$ OV-1 at $100^{\circ} \mathrm{C}, 1.2 \mathrm{~kg} / \mathrm{cm}^{2} \mathrm{He}$, and 2) $3 \mathrm{~mm} \mathrm{i.d.} \times 2 \mathrm{~m}$ length, packed with Porapak $Q$ at $180^{\circ} \mathrm{C}$ to $200^{\circ} \mathrm{C}, 1.0$ to $1.4 \mathrm{~kg} / \mathrm{cm}^{2} \mathrm{He}$.

\section{Skin irritation and corneal opacity}

Skin irritations were caused in the forearms of 4 volunteers by natural spray and artificial solutions. Corneal opacity was caused in the eye of the guinea pig. Artificial solutions were A: acetic acid $80 \%$, caprylic acid $5 \%$, and water $15 \%$, and B: acetic acid $80 \%$ and water $20 \%$ ).

\section{Results AND Discussion}

Total acid in the spray

The spray in each shot was diluted by

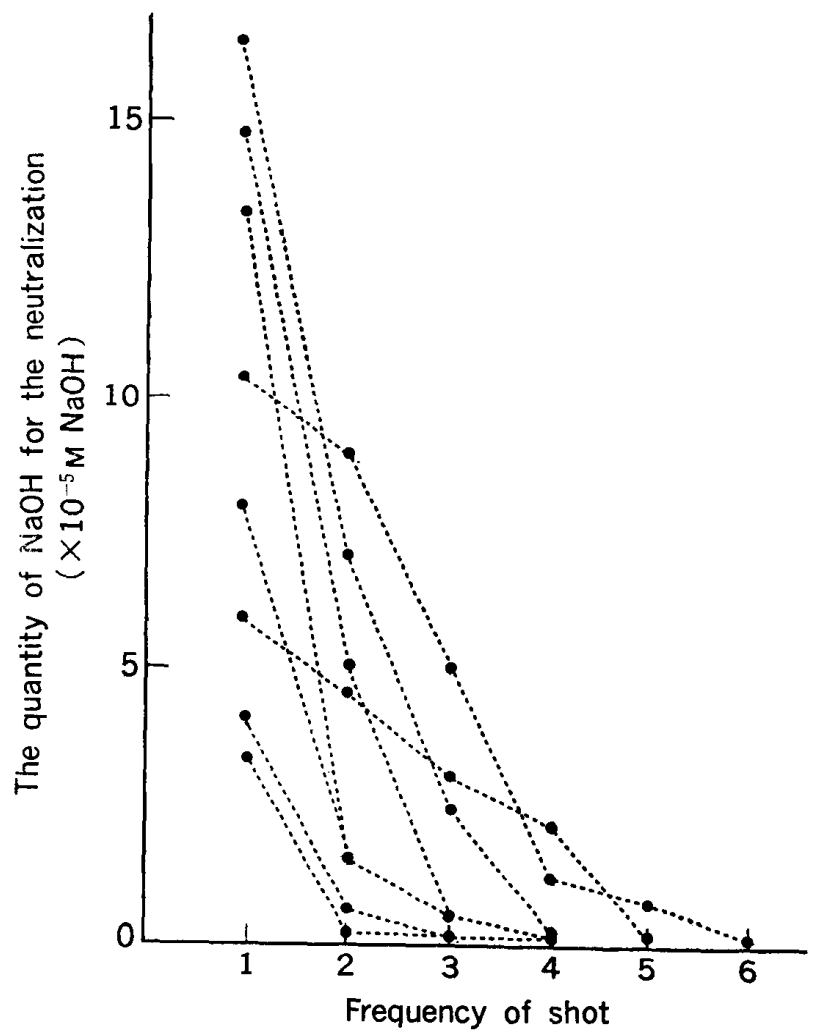

Fig. 1 Total acids neutralized by $\mathrm{NaOH}$ in each shot of the spray of $T$. crucifer adding $100 \mu \mathrm{l}$ of distilled water and the solution was titrated with $1 / 100 \mathrm{~N} \mathrm{NaOH}$ with phenolphthalein as an indicator. As shown in Fig. 1, the amounts of titrable acids were varied between the range of ca. 5 to $15 \times 10^{-5} \mathrm{~mol}$ $(n=8)$ in the 1 st shot. The amounts in the 2nd or 3rd subsequent shots were much more reduced. Judging from this figure, the whipscorpion supposedly discharges an effective secretion of defence within the 1st and 2nd shots.

\section{Identification of the major component}

The spray was diluted to $1 \mathrm{ml}$ with distilled water and $2 \mu$ l of the solution was injected onto the column of Porapak $Q$. The column was maintained at $180^{\circ} \mathrm{C}$ for $10 \mathrm{~min}$. And then the column temperature was raised up to $240^{\circ} \mathrm{C}$ at a rate of $10^{\circ} \mathrm{C} / \mathrm{min}$. Two peaks corresponding to water and acetic acid were observed when the chromatogram was monitored by the total ion peaks (Fig. 2). The mass spectrum of the latter peak showed the molecular ion $\mathrm{m} / \mathrm{e} 60$, $(\mathrm{COOH})^{+}$at $\mathrm{m} / \mathrm{e} 45$ and $\left(\mathrm{CH}_{3} \mathrm{CO}\right)^{+}$at $\mathrm{m} / \mathrm{e}$ 43 , which were identical with those of acetic acid.

No other volatile materials including lower fatty acids such as formic, propionic, butylic, or acrylic acid could be detected in this experiment.

Identification of the lesser volatile component

The spray of $1 \mu l$ was methylated by adding

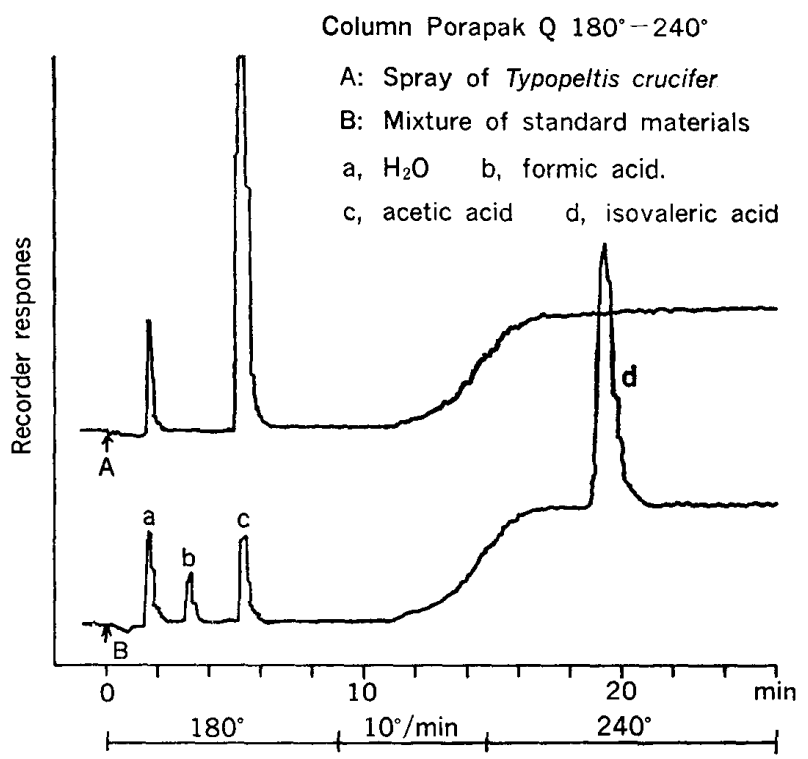

Fig. 2 Gas chromatogram of lower fatty acids 


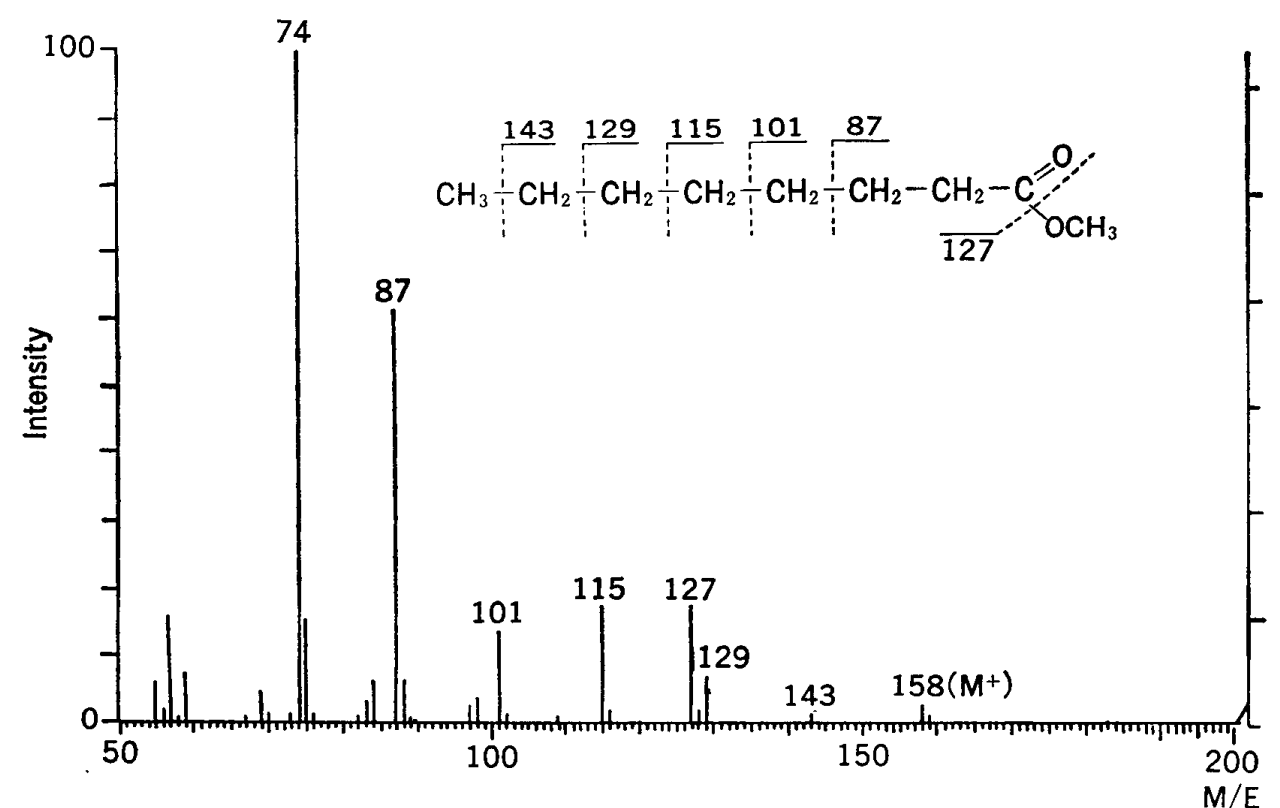

Fig. 3 The mass spectrum of caprylic acid methyl ester in the spray of $T$. crucifer

ether solution of diazomethane and the reaction mixture was examined by combined gas chromatograph-mass spectrometer using the OV-1 column. The column was maintained at $100^{\circ} \mathrm{C}$ and was monitored by the total ion peaks. Mass spectra of the peaks of which there were only 2 in the chromatogram, were measured. The lst peak was a mixture of methyl acetate and the solvent, $n$-hexane, and the mass spectra constituted of the molecular ion at $\mathrm{m} / \mathrm{e} 86,\left(\mathrm{C}_{5} \mathrm{H}_{11}\right)^{+}$at $\mathrm{m} / \mathrm{e} 71$, and $\left(\mathrm{C}_{4} \mathrm{H}_{0}\right)^{+}$ at $\mathrm{m} / \mathrm{e} 57$ from $n$-hexane and of the molecular ion at $\mathrm{m} / \mathrm{e} 74,\left(\mathrm{COOCH}_{3}\right)^{+}$at $\mathrm{m} / \mathrm{e} \mathrm{59}$, and $\left(\mathrm{CH}_{3} \mathrm{CO}\right)^{+}$at $\mathrm{m} / \mathrm{e} 43$ from methyl acetate.
The 2nd peak gave the molecular ion at $\mathrm{m} / \mathrm{e}$ 158 and was identified as methyl caprylate from the result of the fragment analysis of the mass spectrum as shown in Fig. 3. No other higher fatty acids or other volatile materials could be observed in the chromatogram.

Determination of the amounts of water, acetic acid, and caprylic acids in the spray

Water in the spray was determined as follows: to $1 \mu$ l of the spray was added $24 \mu \mathrm{l}$ of acetone. The mixture was injected onto the column of Porapak $Q$ which was maintained in the same condition as that in the identification

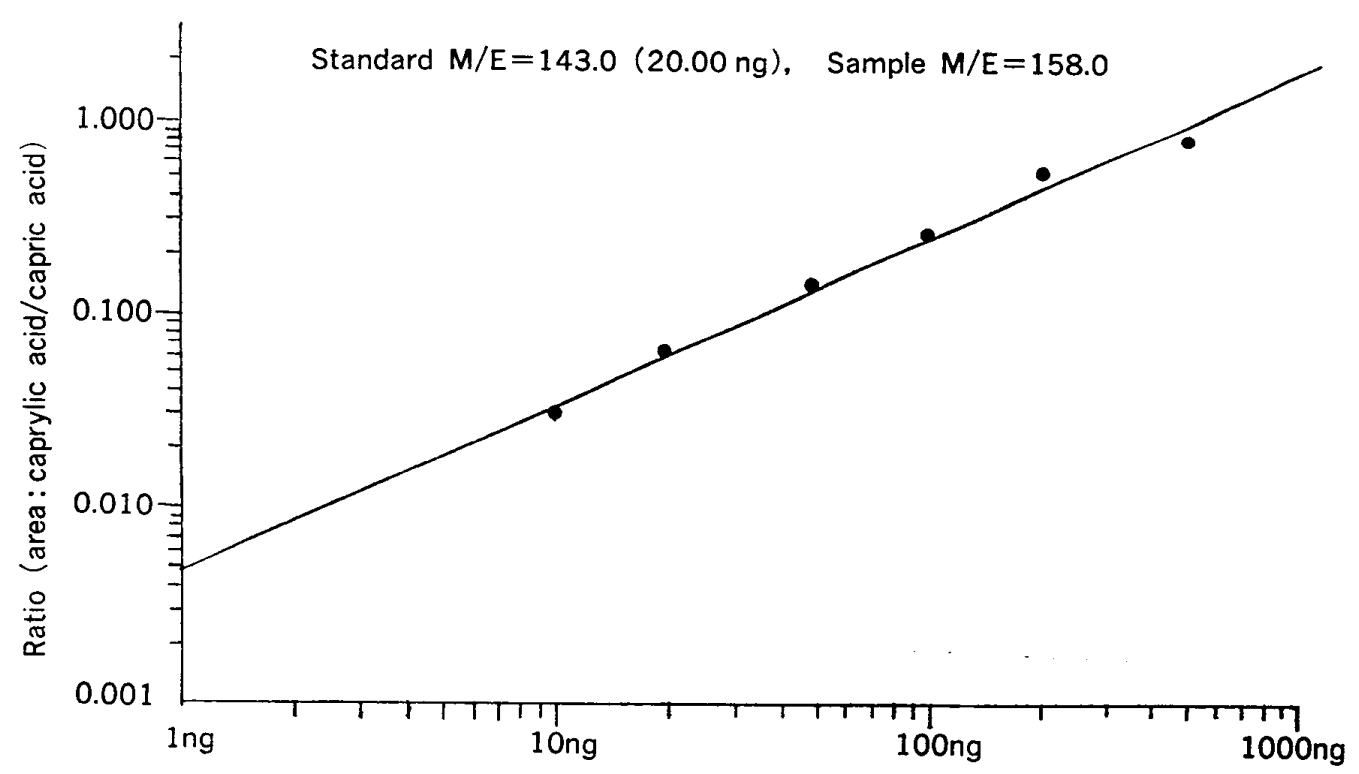

Fig. 4 The working curve of caprylic acid 
of acetic acid. The peak area of molecular ion at $\mathrm{m} / \mathrm{e} 18$ was measured and the amount of water was determined using the absolute working curve of water in acetone. The trace contamination of water in the solvent was compensated by the blank experiment. Water of $12.9 \%(\mathrm{v} / \mathrm{v}) \quad(n=4)$ could be determined in the spray.

Acetic acid in the diluted spray as described before, was determined also by the peak area of the molecular ion at $\mathrm{m} / \mathrm{e} 60$ using the absolute working curve of acetic acid. The average percentage of the acetic acid content was $81.7 \% \quad(\mathrm{v} / \mathrm{v}) \quad(n=7)$.

Caprylic acid was determined as follows: to the spray of $1 \mu \mathrm{l}$ was added $5 \mu \mathrm{g}$ of capric acid as the internal standard, and the mixture was methylated with diazomethane in the previously described manner. After the excess of ether was removed by standing the reaction vial at room temperature without stopper, the residue was dissolved in $n$-hexane and chromatographed using OV-1 column. The amount of caprylic acid was determined by the peak area ratio method with the working curve as shown in Fig. 4. The spray of $1 \mu \mathrm{l}$ contained $53.1 \mu \mathrm{g}$ of caprylic acid which corresponded to $5.4 \%$ $(v / v)$ in the concentration.

Investigation of the occurrence of the other biologically active materials

The spray of 1 shot was diluted by adding $100 \mu \mathrm{l}$ of distilled water and amino acids and active amines such as serotonin or histamine in $10 \mu \mathrm{l}$ of this fluid were directly analysed by a high performance liquid chromatograph. But the amount of such active amines could not be detected at the pmole level. Free amino acids occurred also in negligible amounts in the spray.

Another aliquot of the spray was evaporated to dryness under reduced pressure and hydrolysed by adding $6 \mathrm{~N} \mathrm{HCl}$ at $110^{\circ} \mathrm{C}$ for $24 \mathrm{hr}$. Amino acids in the hydrolysate were also determined. The spray contained materials of a peptide nature, rich in glutamic acid (over $40 \%$ ). Amino acids in the hydrolysate were as follows: aspartic acid, 0.3; serine, 0.3; glutamic acid, 1.1; glycine, 0.5 ; and alanine, 0.3. The other amino acids were below 0.1 pmol. This indicated that the amount of peptide-like materials was also traces and less than $500 \mathrm{ng}$ in 1 shot of spray.

We could not find other biological activity such as mast cell degranulation or the smooth muscle contraction for the nonvolatile materials in the spray.

The active principles discharged from the excretive organs of arthropods as a defensive tool cause irritation and are harmful to the human skin. Aside from the fact that the most of those principles have not been identified, the number of these principles already clarified amounts to more than 100 and is distributed in a wide range of chemical species, including various amines, fatty acids, phenols, aldehydes, terpenes, etc.

The spray of the Asian whipscorpion is mainly composed of acetic acid $(81.7 \%)$, caprylic acid $(5.4 \%)$, and water $(12.9 \%)$. This pattern strikingly resembles that of the American whipscorpion belonging to another genus (Eisner et al., 1961). In general, it has been recognized that the arthropod excretive venoms differ not only in the pattern of their active components but also in their qualities even if they belong taxonomically to the same genus, for example the spray of the carabid beetles, that of the solenopsid ants, the venom of the vespid wasps etc. These tendencies are not necessarily applicable to such an ancestral arthropod as the whipscorpion.

\section{Skin irritation and corneal opacity}

In the human skin (forearm), natural spray produced a painful sensation, which lasted for a short time. Objectively, at the point of contact, depigmentation appeared, followed by erythema with slight swelling. However vesicles and bullae did not appear. Pigmentation appeared after a few days. Scale and pigmentation lasted more than 3 weeks. The artificial solutions produced almost the same skin lesion as the natural spray. A solution produced a painful sensation and permeated into the skin faster than B solution. It is supposed that caprylic acid promotes the permeation of acetic acid as a detergent.

Corneal opacity was caused by both the natural spray and the artificial solutions in the same way. It disappeared completely within 4 days.

\section{Acknowledgements}

The authors express their deep gratitude to Drs. Hideo Ishijima and Tsukasa Kishimoto, Nago Hospital, Dr. Tadao Ishigaki, Ishigaki Hospital, 
Messrs. Kobo Miyara and Sachio Yamashiro for collecting the whipscorpions.

\section{REFERENCES}

Benson, J. R. and P. E. Hare (1975) : o-Phthalaldehyde : Fluorogenic detection of primary amines in the picomoles range. Comparison with fluorescamine and ninhydrin. Proc. Natl. Acad. Sci., U.S.A., 72: 619-622.

Eisner, T., J. Meinwald, A. Moro and R. Ghent (1961) : Defence mechanism of arthropods. I. The composition and function of the spray of the whipscorpion, Mastigoproctus giganteus (Lucas) (Arachnida, Pedipalpida). J. Insect Physiol., 6 : 272-298.

Yoshida, H., T. Nakajima, Y. Ueno, N. Koine, M. Onda, K. Ohe and A. Miyoshi (1978) : Simple and rapid screening method of amino acids and amines in biological samples. Hiroshima J. Med. Sci., 27 : 85-92.
摘 要

アジア産サソリモドキ Typopeltis crucifer Pocock, 1894 の噴射液の化学成分について

サソリモドキ類は世界で約70種が知られ，日本には 1 属 2 種, タイワンサソリモドキ Typopeltis crucifer Pocock, 1894 とアマミサソリモドキ T. stimpsonii (Wood, 1862)を産する。これらは肛門付近から酢酸莫 の強い分泌液を噴射する。米国産大形種 Mastigoproctus giganteus については Eisner et al. (1961) の報 告がある.われわれは沖繩石坦島産タイワンサソリモ ドキの噴射液を，ガスクロマトグラフィー，マススペ クトラム法, 高速液体クロマトグラフィーを用いて調 ベ，その組成は，酢酸 $81.7 \%$ ，カプリル酸 $5.4 \%$ ，水 $12.9 \%$ ，活性アミン，ペプチド様物質は痕跡程度で あった. Eisner の報告では酢酸 $84 \%$,カプリル酸 $5 \%$, 水11\%で，このように地域，属が異なるのに噴射液の 組成がほぼ同様であることは與味深い. 